\title{
JAVAANSCHE WOORDENLIJST.
}

De hieronder behandelde woorden en volzinnen zijn ontleend aan het Javaansche Handschrift, van welks inhoud wij een overzicht gaven in onze levensbeschrijving van Ngajogya's eersten en tweeden Sultan. Het eerste en het laatste gedeelte van dat Handschrift komt voor in onze "Bloemlezing uit Javaansche Proza-geschriften" [Leiden. E. J. Brill. 1893] pag. 127-310. De woorden aan dat in druk verschenen gedeelte ontleend, worden hier beneden aangeduid door Bl.; de overigen door H.S. angeduid komen in het niet-gedrukte, het grootste gedeelte van het Handschrift voor. Het hier volgende is slechts een gedeelte der woorden, die eenige aandacht verdienen, hetzij omdat zij niet in het W.d.b. voorkomen, of wel om nog eenige nadere verklaring van reeds in het W.d.b. voorkomende woorden te geven; de gelegenheid om nog meer woorden te behandelen ontbrak ons. Voor een gedeelte der behandelde woorden kwam ons de vriendelijke en welwillende hulp van eenen Prijaji in de Vorstenlanden ten goede; het kwam verkiezelijk voor zijne in het $\mathrm{J}$ avaansch gegeven verklaringen hier onvertaald op te nemen en aan te duiden door Vkld. Daar hij het Handschrift zelf niet tot zijne beschikking had, gaf hij nu en dan wel eens eene verklaring die nu juist niet op een woord in een bedoeld verband van toepassing was, maar daarom toch niet behoefde achtergehouden te worden.

ๆ

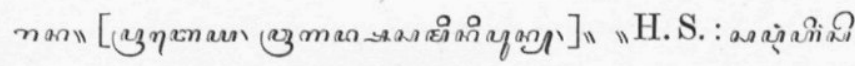

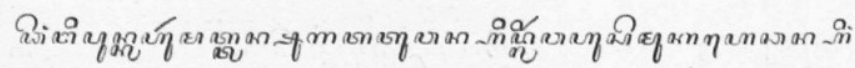

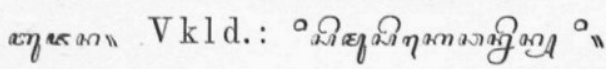

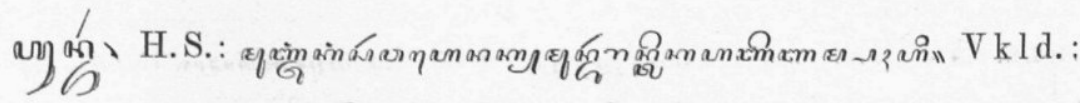
a 